\title{
Awareness on causes, consequences and preventive measures of obesity among urban married women in India
}

\section{Praween Agrawal, Kamla Gupta', Vinod Mishra², Sutapa Agrawal $^{3}$}

Population Council, New Delhi, ${ }^{1}$ Tata Institute of Social Sciences, Mumbai, India, ${ }^{2}$ United Nations,

New York, USA, ${ }^{3}$ South Asia

Network for Chronic Disease, Public Health Foundation of India, New Delhi, India

Address for the Correspondence:

Dr. Sutapa Agrawal, South Asia Network for Chronic Disease (SANCD), Public Health Foundation of India (PHFI), First Floor, C-1/52

Safdarjung Development Area, New Delhi - 110 016, India.

E-mail: sutapa.agrawal@phfi.org

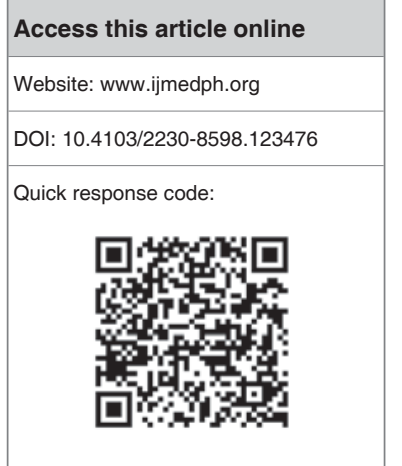

Background: In spite of the numerous chronic diseases that have been linked to obesity, studies focusing on the awareness regarding causes, consequences and strategies to prevent and control of obesity among women are lacking in the literature, especially in developing countries such as India, where obesity is culturally accepted and nurtured and women bearded the highest weight gain in the recent decade. Objective: We explored the awareness regarding causes, consequences and preventive measures of obesity among 325 ever-married aged 20-54 years women with different levels of body mass index (BMI) in the national capital territory of Delhi representing urban India. Materials and Methods: A population based follow-up survey of women systematically selected from the second round of National Family Health Survey (NFHS-2, 1998-99) samples who were re-interviewed after four years in 2003. As a part of qualitative data collection, the respondents were asked to free list open-ended questions on causes, consequences and preventive measures of obesity. Responses were analyzed through Anthropac software package. Results: Over eating was reported as the most important cause of obesity by normal and overweight women whereas obese women reported fried food consumption as the most important cause of weight gain. A few women from each group reported changing lifestyle as a cause of obesity. Also, there were lots of misconceptions about the cause of obesity among women (such as no tension in life, more tension, happiness, constipation, problem in Delhi's water etc.). In terms of the consequences of obesity, the participants were well aware of the common physical consequences. Normal and obese women reported breathlessness as the most important consequence whereas overweight women reported problem in standing and sitting. Regarding preventive measures, overweight and obese women reported 'walking' as most important preventive measure of obesity whereas normal women reported 'doing exercise'. In addition, 'dieting' was reported as the next important preventive measures of obesity by all groups of women. Conclusion: Our study of a fairly large, communitybased sample of women has shown that women were aware of the complex nature of obesity in terms of causes, consequences and a range of potential solutions. The findings are important for public health interventions in obesity care in India. Implementation of health promotion and health education in the community should use effective school education and mass media programme to raise more awareness of the causes, consequences and preventive measures and hammer misconceptions, to combat the growing level of obesity among Indian women.

Key words: Consequences, causes, Delhi, India, obesity, overweight, preventive measures, women

\section{INTRODUCTION}

Obesity (body mass index $(\mathrm{BMI}) \geq 30 \mathrm{~kg} / \mathrm{m}^{2}$ ) is identified as a major public health challenge of the 21 st century across the globe. ${ }^{[1]}$ Currently, an estimated 205 million men and 297 million women over the age of 20 were obese - a total of more than half a billion adults worldwide. ${ }^{[2]}$ Even in countries like India, which are typically known for high prevalence of under nutrition, a significant proportion of overweight and obese people now coexists with those who are undernourished. ${ }^{[3]}$ Most available recent data by National family health survey (NFHS-3 in 2005-2006) from India showed overweight and obesity together among women is $12.6 \%$ (an increase of almost $25 \%$ from NFHS-2, 1998-99) and 
almost similar percentage of underweight and overweight women coexists in urban India (25\% underweight and 23.5\% overweight or obese). ${ }^{[4]}$ The prevalence is more profound in the women of age between 40-49 years (23.7\%), residing in cities (23.5\%), having high qualification $(23.8 \%)$, belonging to Sikh community $(31.6 \%)$ and households in the highest wealth quintile (30.5\%). ${ }^{[5]}$ Current figures in New Delhi indicate that every second person fulfils the criteria of obesity or has excess abdominal fat. ${ }^{[6]}$ In the near future, obesity is likely to emerge as a challenging problem for Indian women. Therefore, in the light of the increasing population weights, it is worthwhile to know how far the population is aware of the causes, consequences of obesity and the remedies taken by the people to avoid obesity or to reduce weight, more specifically among adult women in India who are the sufferer of largest weight gain as compared to men. ${ }^{[4]}$

In spite of the numerous chronic diseases that have been linked to obesity, studies focusing on the level of community awareness, health hazards and strategies to prevent and control of obesity are lacking in the literature, especially in developing countries such as India, where obesity is culturally acknowledged and nurtured. Awareness of any public health disease helps in prevention and in proper action to be initiated. Obesity is known to increase the risk of various diseases and awareness of them is the first step towards taking steps to prevent this. The level of awareness about causes, consequences and preventive measures of obesity is still, to a greater extent, low particularly among women in India and confined to very few individuals affiliated with the health field. The determination of level of awareness among women is therefore an important step to the development of useful interventions intended to lessen this health problem. In this study, we aim to investigate the awareness of women regarding causes and consequences of obesity and the preventive measures to tackle the problem of weight gain among normal weight, overweight and obese women in a community based follow-up study in the national capital territory of Delhi, representing urban India.

\section{MATERIALS AND METHODS}

\section{Study location and population}

The present paper utilises data collected for the Doctoral dissertation by the first author, the title of the thesis being, Dynamics of obesity among women in India: A special reference to Delhi'. Delhi which has a heterogeneous, multicultural population representative of the Indian urban scenario was chosen as the preferred location for this study. Full details of the study have been presented elsewhere. ${ }^{[7]}$ Briefly, during May-June 2003, a follow up survey was carried out in the national capital territory of Delhi using the same sample derived from the National Family Health Survey-2 (NFHS-2) conducted during 1998-99. NFHS-2 collected demographic, socio-economic and health information from a nationally representative sample of 90, 303 ever-married women aged 15-49 years in all 29 states of India covering more than $99 \%$ of the country's population with a response rate of $98 \%$. Details of sample design, including sampling frame are provided in the national survey report. ${ }^{[8]}$
From the 1998-99 NFHS-2 Delhi samples, 325 women aged 15-49 years, systematically chosen from the 1998-99 NFHS-2 Delhi samples were re-interviewed in a follow up survey after four years in 2003 using an interview schedule. Their weights and heights were again recorded (using the same equipment used in NFHS-2) to compute their current body mass index. In addition to these measurements, detailed information was collected on their dietary habits, levels of sedentary lifestyle, along with other socio-demographic characteristics. Information on woman's awareness regarding causes and consequences of obesity and the preventive measures to tackle the problem of weight gain was also sought as a part of the qualitative information. Qualitative data collection technique such as 'free listing' was carried out from the sample population by asking open-ended questions.

\section{Sample Selection, response rate and sample size}

Earlier studies on obesity in India and other developing countries have shown that overweight and obesity are predominant in urban areas and among women. ${ }^{[9,10]}$ Therefore, only urban Primary Sampling Units (PSUs) were chosen for the follow-up survey in Delhi. The sample frame for the follow up survey was fixed to include women in all BMI categories and literacy levels. The aim was to have a sample size of at least 300 women, 100 from each of the three BMI categories (normal, overweight, and obese). At the time of revisit, several issues such as migration, change of address, non-response and non-availability of respondents tend to reduce the desired sample size. Potential loss during follow-up ${ }^{[11]}$ was dealt with increasing the initial sample size (double than required) to get the desired sample size for the study.

In NFHS-2 Delhi sample, 1117, 500 and 203 women were normal, overweight and obese respectively. In NFHS-2 survey questionnaire respondents were asked, 'Would you mind if we come again for a similar study at some future date after a year or so?' Those women who objected for a revisit were excluded from the follow up survey thus there remained 1050 normal, 476 overweight and 177 obese women in the sampling frame. Samples were drawn from each of these three categories through systematic stratified random selection using a random number. From the normal BMI category, every fourth woman and from the overweight category every second woman was drawn. In the obese category all women were included in the sample to get the desired sample size. This resulted into selection of a total of 677 women-262 normal, 238 overweight and 177 obese. For the follow up survey, the addresses of the selected women were obtained from the NFHS-2 Household Questionnaires. Sample size was further reduced due to non-availability of some questionnaires and non-identified addresses. Finally, a total of 595 women-217 normal, 227 overweight and 151 obese were selected for the follow up interview.Details of the samples selection and response rate is illustrated in the schematic diagram [Figure 1].

In the follow-up survey, $57 \%$ of the eligible samples (337 women) were successfully interviewed-113 normal, 124 overweight and 100 obese women. $43 \%$ of the sample ( 258 women) could not be interviewed as they were out of station $(16 \%)$, had migrated $(22 \%)$, their residence was un-located $(1 \%)$, died $(1 \%)$ or refused for an 


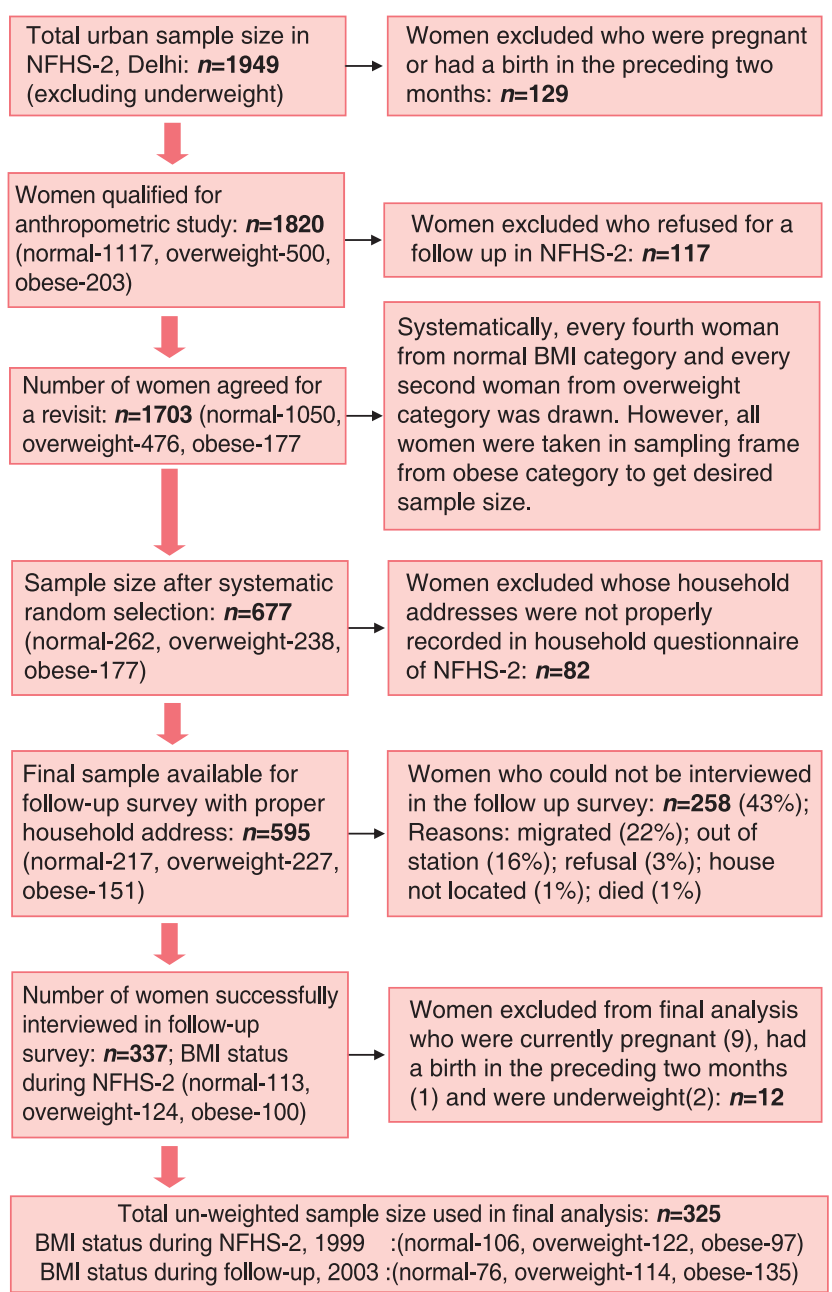

Figure 1: Selection of sample in the follow-up survey and response rate

interview (3\%). Women who were pregnant $(n=9)$ at the time of the follow-up survey, women who had given birth during the two months preceding the survey $(n=2)$ and underweight women $(n=1)$ have been excluded from the final analysis. Therefore, the findings are based on the remaining 325 respondents of the follow up survey. A separate analysis using NFHS-2 data shows that the sociodemographic characteristics of those interviewed and those could not be interviewed in the follow up survey were similar (data not shown) indicating that the follow-up sample appears representative of the NFHS-2 sample population.

\section{Anthropometric measurements}

In NFHS-2 (executed by the field investigators) as well as in the followup survey (executed by the researcher), each ever-married woman was weighed in light clothes with shoes off using a solar-powered digital scale with an accuracy of \pm 100 gms. Their height was also measured using an adjustable wooden measuring board, specifically designed to provide accurate measurements (to the nearest $0.1 \mathrm{~cm}$ ) in a developing country field situation. These data were used to calculate their individual BMIs. Practical and clinical definitions of overweight and obesity are based on the BMI, which is computed by dividing weight (in kilogram) by the square of height (in meter) $\left[\mathrm{kg} / \mathrm{m}^{2}\right] .{ }^{[12]} \mathrm{A}$ woman with a BMI between 25 and 30 is considered to be overweight, a BMI of greater than 30 is considered to be obese. A woman with a BMI between 18.5 and 24.9 is considered normal, and if the BMI is below 18.5 the woman is considered to be underweight. ${ }^{[12]}$

\section{Statistical methods}

Data were analyzed using descriptive statistics. Responses from the free listing have been analyzed through computer software ANTHROPAC ${ }^{1}$ version 4.98 which was developed specifically for this kind of qualitative research.${ }^{[13]}$ ANTHROPAC ${ }^{1}$ provides the frequency, rank and salience (a combination of frequency and rank) for each of the items. ANTHROPAC then employs Johnson's hierarchical clustering and non-metric, multidimensional scaling to identify a consensus model. The results provide a cultural perspective on the clustering of items. For analysis purpose, women have been divided into three groups: normal, overweight and obese. All other analysis was done using SPSS Version 19 (IBM SPSS Statistics, Chicago, IL, USA).

\section{Ethical approval}

The study received ethical approval from the International Institute for Population Science's Ethical Review Board. Informed consent was obtained from all respondents in both NFHS-2 and the follow-up survey before asking questions and before obtaining measurements of their height and weight. The analysis presented in this study is based on secondary analysis of the survey data with all identifying information removed.

\section{RESULTS}

\section{Characteristics of the study population}

Table 1 presents the characteristics of the study population. In the study sample, there were almost equal percentage of overweight $(43.6 \%)$ and obese (39.4\%) women and $17 \%$ were medically obese. Almost one third of the respondents were below 35 years and two thirds were over 35 years of age. The mean age of the respondents was 41.2 years. Over half the study population (58\%) had completed high school education while one-seventh was illiterate. Almost $80 \%$ of the respondents were Hindu, the rest being Muslim, Sikh and Others. Regarding caste/tribe distribution, 'Others' were predominant $(84 \%)$ and there was equal percentage of Scheduled Castes/Tribes (8\%) and other backward Class (8\%). Majority of the respondents $(87 \%)$ belonged to households with a higher standard of living (SLI) whereas less than 14\% women belonged to households with a medium or lower SLI. Majority of women (92\%) were not working except for $8 \%$ [Table 1].

${ }^{1}$ ANTHROPAC is a menu-driven DOS program for collecting and analyzing data on cultural domains. The program helps collect and analyze structured qualitative and quantitative data including freelists, pilesorts, triads, paired comparisons, and ratings. ANTHROPAC's analytical tools include techniques that are unique to Anthropology, such as consensus analysis, as well as standard multivariate tools such as multiple regression, factor analysis, cluster analysis, multidimensional scaling and correspondence analysis. In addition, the program provides a wide variety of data manipulation and transformation tools, plus a full-featured matrix algebra language. 


\begin{tabular}{|c|c|c|}
\hline Characteristics & Percent & Number of women \\
\hline \multicolumn{3}{|l|}{ Current Body Mass Index ${ }^{1}$} \\
\hline Overweight (BMI 25.0-29.99kg/m²) & 43.6 & 103 \\
\hline Obese $\left(\mathrm{BMI} \geq 30.0-34.99 \mathrm{~kg} / \mathrm{m}^{2}\right)$ & 39.4 & 93 \\
\hline Medically Obese $\left(\mathrm{BMI} \geq 35.0 \mathrm{~kg} / \mathrm{m}^{2}\right)$ & 16.9 & 40 \\
\hline \multicolumn{3}{|l|}{ Current age } \\
\hline $20-34$ & 33.1 & 78 \\
\hline $35-54$ & 66.9 & 158 \\
\hline Mean age & 41.2 & 236 \\
\hline \multicolumn{3}{|l|}{ Education $^{2}$} \\
\hline Illiterate & 13.6 & 32 \\
\hline Literate, <middle school complete & 15.3 & 36 \\
\hline Middle school complete & 13.6 & 32 \\
\hline High school complete and above & 57.6 & 136 \\
\hline \multicolumn{3}{|l|}{ Religion } \\
\hline Hindu & 79.7 & 188 \\
\hline Muslim & 8.5 & 20 \\
\hline Sikh or Others ${ }^{3}$ & 11.9 & 28 \\
\hline \multicolumn{3}{|l|}{ Caste/tribe status ${ }^{4}$} \\
\hline Scheduled caste/tribes & 8.1 & 19 \\
\hline Other backward class & 8.1 & 19 \\
\hline Others & 83.9 & 198 \\
\hline \multicolumn{3}{|l|}{ Standard of living index ${ }^{5}$} \\
\hline Low/ Medium & 13.5 & 31 \\
\hline High & 86.5 & 199 \\
\hline \multicolumn{3}{|l|}{ Employment status } \\
\hline Not working & 92.3 & 217 \\
\hline Working & 7.7 & 18 \\
\hline \multicolumn{3}{|l|}{ Media Exposure } \\
\hline Never reads newspapers & 53.4 & 126 \\
\hline Reads newspapers occasionally & 11.0 & 26 \\
\hline Reads newspapers daily & 35.6 & 84 \\
\hline Total & 100.0 & 236 \\
\hline
\end{tabular}

Note: ${ }^{1}$ Women who were pregnant at the time of the survey, or who had given birth during the two months preceding the survey, were excluded from these anthropometric measurements. ${ }^{2}$ lliterate-o years of education, literate but less than middle school complete-1-5 years of education, middle school complete-6-8 years of education, high school complete or more-9+ years of education ${ }^{3 B u d d h i s t, ~ C h r i s t i a n, ~}$ Jain, Jewish, Zoroastrian 4 Scheduled castes and Scheduled tribes are identified by the Government of India as socially and economically backward and needing protection from social injustice and exploitation; Other Backward class category is a diverse collection of intermediate castes that were considered low in the traditional caste hierarchy but are clearly above SC; Others' is a default residual group that enjoys higher status in the caste hierarchy. ${ }^{5}$ Standard of living (SLI) was defined in terms of household assets and material possessions and these have been shown to be reliable and valid measures of household material well-being. It is an index which is based on ownership of a number of different consumer durables and other household items. It is calculated by adding the following scores: House type: 4 for pucca, 2 for semi pucca, o for kach ha; toilet facility: 4 for own flush toilet, 2 for public or shared flush toilet or own pit toilet, 1 for shared or public pit toilet, o for no facility; source of lighting: 2 for electricity, 1 for kerosene, gas or oil, o for other source of lighting; main fuel for cooking: 2 for electricity, liquefied natural gas, or biogas, 1 for coal, charcoal, or kerosene, o for other fuel; source of drinking water: 2 for pipe, hand pump, or well in residence/yard/plot, 1 for public tap, hand pump, or well, o for other water source; separate room for cooking: 1 for yes, o for no; ownership of house: 2 for yes, o for no; ownership of agricultural land: 4 for 5 acres or more, 3 for 2.0-4.9 acres, 2 for less than 2 acres or acreage not known, o for no agricultural land; ownership of irrigated land: 2 if household owns at least some irrigated land, o for no irrigated land; ownership of livestock: 2 if own livestock, o if not own livestock; durable goods ownership: 4 for a car or tractor, 3 each for a moped/scooter/motorcycle, telephone, refrigerator, or colour television, 2 each for a bicycle, electric fan, radio/transistor, sewing machine, black and white television, water pump, bullock cart, or thresher, 1 each for a mattress, pressure cooker, chair, cot/bed, table, or clock/watch. Index scores range from 0-14 for low SLI to $15-24$ for medium SLI to $25-67$ for high SLI.

\begin{tabular}{|c|c|c|c|c|}
\hline Causes of obesity & Frequency & $\begin{array}{l}\text { Resp. } \\
\text { pct }\end{array}$ & $\begin{array}{l}\text { Avg. } \\
\text { rank }\end{array}$ & Smith's S \\
\hline Over eating & 26 & 47 & 1.577 & 0.368 \\
\hline $\begin{array}{l}\text { More fried foods } \\
\text { consumption }\end{array}$ & 14 & 25 & 1.429 & 0.214 \\
\hline No work & 12 & 22 & 1.583 & 0.164 \\
\hline Sitting idly & 6 & 11 & 1.333 & 0.094 \\
\hline No exercise & 5 & 9 & 2.400 & 0.057 \\
\hline Happiness & 5 & 9 & 1.400 & 0.073 \\
\hline No walking & 5 & 9 & 2.600 & 0.044 \\
\hline No tension & 4 & 7 & 2.500 & 0.038 \\
\hline Sleeping & 4 & 7 & 2.000 & 0.048 \\
\hline Intake of oily foods & 4 & 7 & 1.750 & 0.059 \\
\hline Eating disorder & 3 & 5 & 1.667 & 0.036 \\
\hline More rest & 3 & 5 & 2.000 & 0.036 \\
\hline Less work & 3 & 5 & 1.000 & 0.055 \\
\hline $\begin{array}{l}\text { Intake of more non- } \\
\text { veg foods }\end{array}$ & 2 & 4 & 1.500 & 0.027 \\
\hline Milk consumption & 2 & 4 & 2.000 & 0.027 \\
\hline Sweet consumption & 2 & 4 & 2.000 & 0.024 \\
\hline Ghee consumption & 2 & 4 & 1.500 & 0.027 \\
\hline Swelling of body & 1 & 2 & 1.000 & 0.018 \\
\hline Diseases & 1 & 2 & 2.000 & 0.012 \\
\hline Genetics & 1 & 2 & 2.000 & 0.014 \\
\hline Thyroid problem & 1 & 2 & 1.000 & 0.018 \\
\hline Butter consumption & 1 & 2 & 3.000 & 0.009 \\
\hline Junk food consumption & 1 & 2 & 3.000 & 0.011 \\
\hline Hormonal imbalance & 1 & 2 & 4.000 & 0.007 \\
\hline Diabetes & 1 & 2 & 2.000 & 0.015 \\
\hline More tension & 1 & 2 & 2.000 & 0.009 \\
\hline Lifestyle & 1 & 2 & 3.000 & 0.009 \\
\hline No balanced diet & 1 & 2 & 2.000 & 0.009 \\
\hline Fruit consumption & 1 & 2 & 3.000 & 0.009 \\
\hline Juice consumption & 1 & 2 & 4.000 & 0.005 \\
\hline Infertility & 1 & 2 & 1.000 & 0.018 \\
\hline Total/Average & 116 & 2.109 & & \\
\hline
\end{tabular}

\section{Awareness regarding causes of obesity}

Tables 2, 3 and 4 present the results of free listing about awareness regarding causes of obesity among normal, overweight and obese women respectively. Over eating was reported as the most important cause of obesity by normal and overweight women whereas; obese women reported consumption of fried foods as the most important cause of weight gain. On the other hand, more fried food consumption was reported as the second most important cause of weight gain by normal and overweight women whereas over eating was reported by obese women. The next important cause for obesity reported by the normal and overweight women was 'not doing any work'. However, obese women blamed idle sitting as a major cause of becoming obese. Among other causes, lack of physical exercise was reported by a higher proportion of obese and overweight women, whereas 'no walking' was reported by normal women. A higher proportion of obese and overweight 


\begin{tabular}{|c|c|c|c|c|}
\hline Causes of obesity & Frequency & Resp. pct & Avg. rank & Smith's S \\
\hline Over eating & 43 & 45 & 1.372 & 0.391 \\
\hline Eating of fried foods & 26 & 27 & 1.808 & 0.190 \\
\hline More rest & 20 & 21 & 1.800 & 0.146 \\
\hline No work & 19 & 20 & 2.000 & 0.136 \\
\hline No exercise & 15 & 16 & 2.000 & 0.096 \\
\hline Tension & 8 & 8 & 2.000 & 0.058 \\
\hline Sweet consumption & 8 & 8 & 2.878 & 0.036 \\
\hline No walking & 8 & 8 & 2.000 & 0.053 \\
\hline Ghee consumption & 8 & 8 & 1.750 & 0.059 \\
\hline Medicines & 5 & 5 & 1.400 & 0.046 \\
\hline Hereditary & 5 & 5 & 2.800 & 0.030 \\
\hline Eating disorder & 5 & 5 & 1.400 & 0.043 \\
\hline Disease & 5 & 5 & 1.800 & 0.035 \\
\hline Happiness & 4 & 4 & 1.750 & 0.030 \\
\hline Intake of oily food & 4 & 4 & 2.500 & 0.024 \\
\hline Sleeping & 3 & 3 & 2.333 & 0.018 \\
\hline Age & 3 & 3 & 1.667 & 0.024 \\
\hline Menstrual problem & 3 & 3 & 2.000 & 0.018 \\
\hline Oil consumption & 2 & 2 & 2.000 & 0.024 \\
\hline Food habits & 2 & 2 & 1.500 & 0.019 \\
\hline Anaemia & 2 & 2 & 1.500 & 0.016 \\
\hline Frequent eating out & 2 & 2 & 2.500 & 0.016 \\
\hline No tension & 2 & 2 & 2.000 & 0.017 \\
\hline Junk food consumption & 2 & 2 & 2.000 & 0.009 \\
\hline Sugar consumption & 2 & 2 & 1.500 & 0.012 \\
\hline Hormonal imbalance & 2 & 2 & 2.500 & 0.013 \\
\hline Family planning (sterilization) & 2 & 2 & 1.000 & 0.017 \\
\hline Blood becomes water & 1 & 1 & 3.000 & 0.013 \\
\hline Internal body problem & 1 & 1 & 5.000 & 0.021 \\
\hline More glucose consumption & 1 & 1 & 1.000 & 0.003 \\
\hline Problem in Delhi's water & 1 & 1 & 1.000 & 0.003 \\
\hline Operation & 1 & 1 & 1.000 & 0.010 \\
\hline Gastric & 1 & 1 & 2.000 & 0.010 \\
\hline Eating pulses & 1 & 1 & 4.000 & 0.010 \\
\hline Irregular time of eating & 1 & 1 & 1.000 & 0.005 \\
\hline Eating rice & 1 & 1 & 2.000 & 0.010 \\
\hline Eating more Urad dal (a type of Indian pulse) & 1 & 1 & 3.000 & 0.007 \\
\hline Attending party & 1 & 1 & 4.000 & 0.003 \\
\hline Not eating green vegetables & 1 & 1 & 2.000 & 0.003 \\
\hline Spicy food consumption & 1 & 1 & 4.000 & 0.009 \\
\hline After delivery & 1 & 1 & 1.000 & 0.003 \\
\hline Wealth and prosperity & 1 & 1 & 4.000 & 0.010 \\
\hline Changing lifestyle & 1 & 1 & 5.000 & 0.004 \\
\hline Carelessness & 1 & 1 & 3.000 & 0.002 \\
\hline More calorie consumption & 1 & 1 & 3.000 & 0.003 \\
\hline Fat consumption & 1 & 1 & 1.000 & 0.005 \\
\hline Egg consumption & 1 & 1 & 3.000 & 0.010 \\
\hline Total/Average & 230 & 2.396 & & \\
\hline
\end{tabular}

women reported 'having tension' as a cause of obesity whereas 'happiness' or 'having no tension' was reported by normal women. Another common cause for obesity reported by overweight and obese women was eating sweets. It is interesting to find out that sterilization operation as well as operation for other medical ailments was reported as a cause of obesity by a substantial proportion of obese women than overweight women However, none of the normal women reported any type of operation as a cause. A few women from each group also reported changing lifestyle as a cause of obesity. 


\begin{tabular}{|c|c|c|c|c|}
\hline Causes of obesity & Frequency & $\begin{array}{l}\text { Resp. } \\
\text { pct }\end{array}$ & $\begin{array}{l}\text { Avg. } \\
\text { rank }\end{array}$ & Smith's S \\
\hline Eating of fried foods & 37 & 36 & 1.541 & 0.275 \\
\hline Over eating & 37 & 36 & 1.568 & 0.278 \\
\hline Sitting & 20 & 19 & 1.900 & 0.135 \\
\hline No exercise & 11 & 11 & 2.000 & 0.062 \\
\hline $\begin{array}{l}\text { More sweet } \\
\text { consumption }\end{array}$ & 10 & 10 & 2.300 & 0.058 \\
\hline No work & 8 & 8 & 1.500 & 0.063 \\
\hline Eating more rice & 8 & 8 & 2.125 & 0.055 \\
\hline Tension & 8 & 8 & 1.750 & 0.060 \\
\hline No walking & 7 & 7 & 1.857 & 0.043 \\
\hline Medical surgery & 6 & 6 & 1.000 & 0.058 \\
\hline Less work & 6 & 6 & 1.833 & 0.037 \\
\hline $\begin{array}{l}\text { More ghee } \\
\text { consumption }\end{array}$ & 5 & 5 & 2.000 & 0.034 \\
\hline $\begin{array}{l}\text { Family Planning } \\
\text { (sterilization) }\end{array}$ & 5 & 5 & 1.600 & 0.037 \\
\hline Food habits & 5 & 5 & 1.600 & 0.038 \\
\hline $\begin{array}{l}\text { Spicy food } \\
\text { consumption }\end{array}$ & 4 & 4 & 3.000 & 0.018 \\
\hline Hereditary & 4 & 4 & 1.000 & 0.035 \\
\hline Eating fatty foods & 4 & 4 & 1.250 & 0.014 \\
\hline Potato consumption & 3 & 3 & 3.333 & 0.018 \\
\hline Sleeping & 3 & 3 & 2.000 & 0.010 \\
\hline Thyroid problem & 3 & 3 & 2.000 & 0.019 \\
\hline $\begin{array}{l}\text { Eating Non-vegetarian } \\
\text { foods }\end{array}$ & 3 & 3 & 1.000 & 0.010 \\
\hline Eating disorder & 2 & 2 & 1.500 & 0.019 \\
\hline Happiness & 2 & 2 & 1.000 & 0.014 \\
\hline $\begin{array}{l}\text { Eating outside food } \\
\text { daily }\end{array}$ & 2 & 2 & 1.000 & 0.019 \\
\hline After delivery & 2 & 2 & 3.000 & 0.019 \\
\hline Medicines & 2 & 2 & 1.000 & 0.006 \\
\hline More tea consumption & 2 & 2 & 3.000 & 0.019 \\
\hline Hormonal imbalance & 2 & 2 & 2.000 & 0.010 \\
\hline Abortion & 2 & 2 & 2.000 & 0.007 \\
\hline More salt consumption & 1 & 1 & 1.000 & 0.006 \\
\hline No tension & 1 & 1 & 2.000 & 0.010 \\
\hline Diseases & 1 & 1 & 2.000 & 0.005 \\
\hline Standing & 1 & 1 & 1.000 & 0.006 \\
\hline Milk consumption & 1 & 1 & 1.000 & 0.010 \\
\hline Change in lifestyle & 1 & 1 & 3.000 & 0.010 \\
\hline Glucose consumption & 1 & 1 & 1.000 & 0.003 \\
\hline Wrong habits & 1 & 1 & 1.000 & 0.010 \\
\hline More rest & 1 & 1 & 2.600 & 0.008 \\
\hline Sugar consumption & 1 & 1 & 1.000 & 0.002 \\
\hline Constipation & 1 & 1 & 6.000 & 0.002 \\
\hline Total/Average & 224 & 2.154 & & \\
\hline
\end{tabular}

\section{Awareness regarding consequences of obesity}

Tables 5, 6 and 7 present the results of free listing about awareness regarding consequences of obesity among normal, overweight and obese women, respectively. Normal and obese women reported 'breathlessness' as the most important

\begin{tabular}{|c|c|c|c|c|}
\hline $\begin{array}{l}\text { Consequences of } \\
\text { obesity }\end{array}$ & Frequency & $\begin{array}{l}\text { Resp. } \\
\text { pct }\end{array}$ & $\begin{array}{l}\text { Avg. } \\
\text { rank }\end{array}$ & Smith's S \\
\hline Breathlessness & 36 & 52 & 1.611 & 0.398 \\
\hline $\begin{array}{l}\text { Problem in standing } \\
\text { and sitting }\end{array}$ & 32 & 46 & 1.344 & 0.386 \\
\hline Problem in working & 22 & 32 & 1.682 & 0.235 \\
\hline Problem in walking & 18 & 26 & 1.667 & 1.191 \\
\hline Leads to diseases & 9 & 13 & 1.889 & 0.083 \\
\hline Cause excessive fatigue & 5 & 7 & 2.600 & 0.035 \\
\hline Cause pain in legs & 4 & 6 & 2.000 & 0.034 \\
\hline $\begin{array}{l}\text { Leads to swelling of } \\
\text { body }\end{array}$ & 4 & 6 & 2.250 & 0.029 \\
\hline $\begin{array}{l}\text { Cause high blood } \\
\text { pressure }\end{array}$ & 4 & 6 & 2.250 & 0.035 \\
\hline Cause joint pain & 3 & 4 & 2.000 & 0.024 \\
\hline Cause diabetes & 3 & 4 & 2.000 & 0.027 \\
\hline $\begin{array}{l}\text { Problem in doing } \\
\text { household works }\end{array}$ & 3 & 4 & 2.333 & 0.019 \\
\hline Cannot run & 2 & 3 & 1.500 & 0.024 \\
\hline Indigestion & 2 & 3 & 3.000 & 0.017 \\
\hline Leads to body pain & 2 & 3 & 1.000 & 0.029 \\
\hline $\begin{array}{l}\text { Causes pain in hands } \\
\text { and legs }\end{array}$ & 1 & 1 & 1.000 & 0.014 \\
\hline Looks ugly & 1 & 1 & 3.000 & 0.007 \\
\hline Causes back pain & 1 & 1 & 2.000 & 0.010 \\
\hline $\begin{array}{l}\text { Causes low blood } \\
\text { pressure }\end{array}$ & 1 & 1 & 4.000 & 0.006 \\
\hline Problem in clothing & 1 & 1 & 3.000 & 0.005 \\
\hline $\begin{array}{l}\text { Problem in climbing } \\
\text { staircase }\end{array}$ & 1 & 1 & 3.000 & 0.005 \\
\hline $\begin{array}{l}\text { Feelings of } \\
\text { uneasiness }\end{array}$ & 1 & 1 & 2.000 & 0.010 \\
\hline Becomes less active & 1 & 1 & 1.000 & 0.014 \\
\hline Total/Average & 157 & 2.275 & & \\
\hline
\end{tabular}

consequence of obesity whereas overweight women reported problem in standing and sitting. On the other hand, problem in standing and sitting was reported as the second important consequence of obesity by normal and obese women whereas breathlessness was reported by overweight women. Normal women reported 'problem while working' as the next important consequence of obesity whereas 'problem while walking' was reported by overweight and obese women.

Among the other consequences, occurrence of diseases was highly reported by almost all groups of women. It was interesting to find out that 'bad figure' and 'clothes not fitting' were reported as consequences of obesity by a higher proportion of obese women than overweight women. However, none of the normal women reported this type of consequence. Also, common problems like climbing staircase, excessive fatigue, joint pain and leg pain were reported by a few women from each group. A few overweight and obese women have also reported that people make fun of them. Some overweight women even reported 'loss of everything' and 'root cause of all diseases' as the consequence of obesity. 


\begin{tabular}{|c|c|c|c|c|}
\hline $\begin{array}{l}\text { Consequences } \\
\text { of obesity }\end{array}$ & Frequency & $\begin{array}{l}\text { Resp. } \\
\text { pct }\end{array}$ & $\begin{array}{l}\text { Avg. } \\
\text { rank }\end{array}$ & Smith's S \\
\hline $\begin{array}{l}\text { Problem in standing and } \\
\text { sitting }\end{array}$ & 49 & 44 & 1.408 & 0.365 \\
\hline Breathlessness & 45 & 40 & 1.689 & 0.292 \\
\hline Problem in walking & 33 & 29 & 1.758 & 0.199 \\
\hline Leads to diseases & 19 & 17 & 1.632 & 0.126 \\
\hline Problem in working & 19 & 17 & 1.526 & 0.128 \\
\hline Leads to laziness & 10 & 9 & 2.100 & 0.052 \\
\hline Looks ugly & 7 & 6 & 1.857 & 0.042 \\
\hline Problem in sitting & 6 & 5 & 1.333 & 0.049 \\
\hline $\begin{array}{l}\text { Problem in climbing } \\
\text { staircase }\end{array}$ & 6 & 5 & 1.833 & 0.036 \\
\hline Feeling of tiredness & 5 & 4 & 2.400 & 0.022 \\
\hline $\begin{array}{l}\text { Leads to high blood } \\
\text { pressure }\end{array}$ & 4 & 4 & 1.750 & 0.028 \\
\hline Heart problem & 3 & 3 & 2.333 & 0.016 \\
\hline Problem in sweeping & 3 & 3 & 2.000 & 0.016 \\
\hline Leads to bodily weakness & 3 & 3 & 1.000 & 0.027 \\
\hline Problem in fitting of cloths & 2 & 2 & 2.000 & 0.012 \\
\hline Bad figure & 2 & 2 & 1.500 & 0.015 \\
\hline Loss of self confidence & 2 & 2 & 2.500 & 0.007 \\
\hline Slow speed of work & 2 & 2 & 2.000 & 0.013 \\
\hline Joint pain & 2 & 2 & 2.000 & 0.004 \\
\hline Diabetes & 2 & 2 & 2.500 & 0.009 \\
\hline Leg pain & 2 & 2 & 2.500 & 0.006 \\
\hline Running problem & 2 & 2 & 1.500 & 0.004 \\
\hline People make fun & 1 & 1 & 1.000 & 0.004 \\
\hline Sleeping problem & 1 & 1 & 2.000 & 0.009 \\
\hline Mental tension & 1 & 1 & 2.000 & 0.004 \\
\hline Loss of everything & 1 & 1 & 1.000 & 0.009 \\
\hline Problem in washing & 1 & 1 & 2.000 & 0.004 \\
\hline Problem in standing & 1 & 1 & 2.000 & 0.006 \\
\hline Physical problem & 1 & 1 & 2.000 & 0.004 \\
\hline Body pain & 1 & 1 & 2.000 & 0.006 \\
\hline Gastric problem & 1 & 1 & 2.000 & 0.006 \\
\hline Cannot eat fried foods & 1 & 1 & 1.000 & 0.009 \\
\hline Dizziness & 1 & 1 & 1.000 & 0.009 \\
\hline Cannot sit in jhula & 1 & 1 & 2.000 & 0.004 \\
\hline Root cause of all diseases & 1 & 1 & 3.000 & 0.004 \\
\hline Feels uncomfortable & 1 & 1 & 3.000 & 0.003 \\
\hline Knee pain & 1 & 1 & 2.000 & 0.004 \\
\hline Blood sugar problem & 1 & 1 & 1.000 & 0.009 \\
\hline Pain in hands and legs & 1 & 1 & 2.000 & 0.009 \\
\hline Problem in washing cloths & 1 & 1 & 2.000 & 0.004 \\
\hline Looks fat & 1 & 1 & 2.000 & 0.004 \\
\hline Total/Average & 116 & 2.109 & & \\
\hline
\end{tabular}

\section{Awareness regarding preventive measures of obesity}

Tables 8, 9 and 10 present the results of free listing about awareness regarding preventive measures of obesity among normal, overweight and obese women, respectively. Overweight and obese women reported 'walking' as most important preventive measure of obesity whereas normal women reported

\begin{tabular}{|c|c|c|c|c|}
\hline $\begin{array}{l}\text { Consequences } \\
\text { of obesity }\end{array}$ & Frequency & $\begin{array}{l}\text { Resp. } \\
\text { pct }\end{array}$ & $\begin{array}{l}\text { Avg. } \\
\text { rank }\end{array}$ & Smith's S \\
\hline Breathlessness & 62 & 47 & 1.677 & 0.358 \\
\hline $\begin{array}{l}\text { Problem in standing } \\
\text { and sitting }\end{array}$ & 51 & 38 & 1.510 & 0.303 \\
\hline Problem in walking & 39 & 29 & 1.667 & 0.219 \\
\hline Problem in working & 31 & 23 & 1.903 & 0.153 \\
\hline Leads to diseases & 19 & 14 & 1.895 & 0.102 \\
\hline Leads to bad figure & 10 & 8 & 2.100 & 0.043 \\
\hline Causes arthritis & 9 & 7 & 2.222 & 0.042 \\
\hline Problem in sitting & 8 & 6 & 1.375 & 0.051 \\
\hline $\begin{array}{l}\text { Problem in fittings } \\
\text { of cloth }\end{array}$ & 8 & 6 & 2.125 & 0.038 \\
\hline $\begin{array}{l}\text { Leads to high blood } \\
\text { pressure }\end{array}$ & 6 & 5 & 1.500 & 0.039 \\
\hline Cause leg pain & 6 & 5 & 1.667 & 0.035 \\
\hline Cause laziness & 6 & 5 & 2.333 & 0.024 \\
\hline $\begin{array}{l}\text { Problem in climbing } \\
\text { staircase }\end{array}$ & 5 & 4 & 2.800 & 0.014 \\
\hline Problem in standing & 5 & 4 & 1.400 & 0.031 \\
\hline Cause diabetes & 4 & 3 & 3.250 & 0.013 \\
\hline Sweeping & 4 & 3 & 2.000 & 0.019 \\
\hline $\begin{array}{l}\text { Leads to pain in hands } \\
\text { and legs }\end{array}$ & 3 & 2 & 1.333 & 0.019 \\
\hline Looks ugly & 3 & 2 & 2.667 & 0.013 \\
\hline Feelings of uneasiness & 2 & 2 & 1.500 & 0.011 \\
\hline $\begin{array}{l}\text { Feeling of excessive } \\
\text { fatigue }\end{array}$ & 2 & 2 & 2.000 & 0.005 \\
\hline Feeling of tiredness & 2 & 2 & 1.500 & 0.013 \\
\hline $\begin{array}{l}\text { Leads to swelling } \\
\text { of body }\end{array}$ & 2 & 2 & 1.000 & 0.010 \\
\hline $\begin{array}{l}\text { Problem in wearing } \\
\text { cloths }\end{array}$ & 2 & 2 & 1.000 & 0.011 \\
\hline $\begin{array}{l}\text { Leads to gastric } \\
\text { problem }\end{array}$ & 1 & 2 & 5.000 & 0.008 \\
\hline $\begin{array}{l}\text { Causes bodily } \\
\text { weakness }\end{array}$ & 1 & 1 & 3.000 & 0.008 \\
\hline Causes body pain & 1 & 1 & 3.000 & 0.002 \\
\hline Cannot run & 1 & 1 & 1.000 & 0.003 \\
\hline Loss of sleep & 1 & 1 & 2.000 & 0.003 \\
\hline $\begin{array}{l}\text { Cannot wear high heel } \\
\text { sleeper }\end{array}$ & 1 & 1 & 2.000 & 0.008 \\
\hline People make fun & 1 & 1 & 4.000 & 0.004 \\
\hline Spot in clothes & 1 & 1 & 1.000 & 0.004 \\
\hline Causes tension & 1 & 1 & 2.000 & 0.002 \\
\hline $\begin{array}{l}\text { Root cause of every } \\
\text { problem }\end{array}$ & 1 & 1 & 2.000 & 0.008 \\
\hline Causes knee pain & 1 & 1 & 1.000 & 0.004 \\
\hline Problem in stomach & 1 & 1 & 2.000 & 0.004 \\
\hline Heart problem & 1 & 1 & 2.000 & 0.008 \\
\hline Asthma problem & 1 & 1 & 1.000 & 0.006 \\
\hline Looks over aged & 1 & 1 & 2.000 & 0.004 \\
\hline $\begin{array}{l}\text { Feel shy in moving } \\
\text { around }\end{array}$ & 1 & 1 & 3.000 & 0.008 \\
\hline Cannot eat outside & 1 & 1 & 3.000 & 0.004 \\
\hline $\begin{array}{l}\text { Problem in slipping } \\
\text { through door }\end{array}$ & 1 & 1 & 2.000 & 0.003 \\
\hline Total/Average & 307 & 2.308 & & \\
\hline
\end{tabular}




\begin{tabular}{|c|c|c|c|c|}
\hline $\begin{array}{l}\text { Preventive measures of } \\
\text { obesity }\end{array}$ & Frequency & $\begin{array}{l}\text { Resp. } \\
\text { pct }\end{array}$ & $\begin{array}{l}\text { Avg. } \\
\text { rank }\end{array}$ & Smith's S \\
\hline Exercise & 24 & 63 & 1.417 & 0.511 \\
\hline Walking & 14 & 37 & 1.643 & 0.285 \\
\hline Dieting & 12 & 32 & 1.667 & 0.219 \\
\hline More work & 5 & 13 & 1.600 & 0.092 \\
\hline No fried food & 4 & 11 & 1.500 & 0.086 \\
\hline Running & 2 & 5 & 2.500 & 0.022 \\
\hline Yoga & 1 & 3 & 2.000 & 0.018 \\
\hline Intake of boiled food & 1 & 3 & 2.000 & 0.013 \\
\hline Swimming & 1 & 3 & 4.000 & 0.007 \\
\hline Intake of balanced diet & 1 & 3 & 1.000 & 0.026 \\
\hline Less consumption of rice & 1 & 3 & 1.000 & 0.026 \\
\hline Sweeping & 1 & 3 & 1.000 & 0.026 \\
\hline Working & 1 & 3 & 1.000 & 0.026 \\
\hline Intake of lemon water & 1 & 3 & 1.000 & 0.026 \\
\hline Fasting & 1 & 3 & 1.000 & 0.026 \\
\hline Care of body & 1 & 3 & 2.000 & 0.013 \\
\hline Jogging & 1 & 3 & 2.000 & 0.018 \\
\hline Cycling & 1 & 3 & 4.000 & 0.007 \\
\hline Continuous movement & 1 & 3 & 1.000 & 0.026 \\
\hline Doing household work & 1 & 3 & 2.000 & 0.013 \\
\hline Total/Average & 75 & 1.974 & & \\
\hline
\end{tabular}

'exercise'. On the other hand, overweight and obese women reported exercise as the second important preventive measure of obesity whereas walking was reported by normal women. In addition, dieting was reported as the next important preventive measure of obesity by all groups of women. Among the other preventive measures, 'precautions in diets' (like eating less fried foods and less sweets consumption) and 'more physical work' were reported by all the groups of women. A few obese women reported visiting gymnasium and use of machines while doing exercise as preventive measures.

\section{DISCUSSION}

This is the first empirical evidence of awareness level among urban women in a developing country such as India, which is facing increasing level of obesity in its adult women population. Our study shows that awareness about the causes, consequences and preventive measures of obesity is though almost quite similar among Indian women; the perception varies according to the differential in the BMI of individual. Women reported, overeating, fried food eating and inactivity as a major cause of obesity which is similar to a finding by Tiwari et al. ${ }^{[14]}$ who found that a majority of the females considered over eating, childbirth and reduced activity as the possible causes of their obesity and also obesity in other persons. Women with higher BMI have reported more varieties of consequences than women with a normal BMI since overweight and obese women themselves have experienced the consequences of being

\begin{tabular}{|c|c|c|c|c|}
\hline $\begin{array}{l}\text { Preventive measures } \\
\text { of obesity }\end{array}$ & Frequency & $\begin{array}{c}\text { Resp. } \\
\text { pct }\end{array}$ & $\begin{array}{l}\text { Avg. } \\
\text { rank }\end{array}$ & Smith's S \\
\hline Walking & 37 & 52 & 1.568 & 0.412 \\
\hline Exercise & 34 & 48 & 1.559 & 0.391 \\
\hline Dieting & 26 & 37 & 1.808 & 0.264 \\
\hline No fried foods & 7 & 10 & 2.571 & 0.050 \\
\hline Working & 6 & 8 & 2.167 & 0.060 \\
\hline Intake of less fried food & 6 & 8 & 1.667 & 0.059 \\
\hline $\begin{array}{l}\text { Intake of lemon water at } \\
\text { morning }\end{array}$ & 4 & 6 & 1.500 & 0.042 \\
\hline Household work & 4 & 6 & 2.000 & 0.035 \\
\hline Less sweets & 3 & 4 & 2.000 & 0.026 \\
\hline Yoga & 3 & 4 & 1.333 & 0.035 \\
\hline More salad & 2 & 3 & 1.500 & 0.023 \\
\hline Skipping & 2 & 3 & 2.000 & 0.021 \\
\hline Running & 2 & 3 & 2.000 & 0.014 \\
\hline No cold drinks & 2 & 3 & 4.000 & 0.008 \\
\hline Less sugar & 2 & 3 & 2.000 & 0.019 \\
\hline No ghee & 1 & 3 & 1.000 & 0.014 \\
\hline Honey & 1 & 1 & 2.000 & 0.011 \\
\hline Self control & 1 & 1 & 3.000 & 0.005 \\
\hline No junk foods & 1 & 1 & 4.000 & 0.006 \\
\hline Jogging & 1 & 1 & 3.000 & 0.007 \\
\hline Herbal medicines & 1 & 1 & 2.000 & 0.007 \\
\hline No sweets & 1 & 1 & 2.000 & 0.009 \\
\hline Swimming & 1 & 1 & 4.000 & 0.004 \\
\hline Walking after every meal & 1 & 1 & 2.000 & 0.007 \\
\hline Intake of boiled foods & 1 & 1 & 1.000 & 0.014 \\
\hline Skip food at night & 1 & 1 & 2.000 & 0.011 \\
\hline Less tea & 1 & 1 & 3.000 & 0.007 \\
\hline No tension & 1 & 1 & 3.000 & 0.005 \\
\hline No potato & 1 & 1 & 2.000 & 0.009 \\
\hline No rice & 1 & 1 & 3.000 & 0.014 \\
\hline Less ghee & 1 & 1 & 1.000 & 0.014 \\
\hline Changing food habits & 1 & 1 & 1.000 & 0.007 \\
\hline No sugar & 1 & 1 & 2.000 & 0.007 \\
\hline Total/Average & 158 & 2.225 & & \\
\hline
\end{tabular}

obese in their day-to-day life. In terms of the consequences of obesity, respondents were well aware of the common physical consequences. Walking, exercise and dieting as preventive measures were known to a substantial number of women. These findings suggest that future intervention strategies should pay particular attention to physical activity, inactivity, and body image attitudes.

Obesity is now well recognized as a disease in its own right, one which is largely preventable through changes in life style. This fact, together with its association with the leading causes of illness and death, has made obesity a high priority problem in the World. ${ }^{[15]}$ However, without societal changes, a steadily rising proportion of adult will develop many medical complications of obesity. The rising epidemic 


\begin{tabular}{|c|c|c|c|c|}
\hline $\begin{array}{l}\text { Preventive measures } \\
\text { of obesity }\end{array}$ & Frequency & $\begin{array}{l}\text { Resp. } \\
\text { pct }\end{array}$ & $\begin{array}{l}\text { Avg. } \\
\text { rank }\end{array}$ & Smith's S \\
\hline Walking & 45 & 60 & 1.711 & 0.426 \\
\hline Exercise & 42 & 56 & 1.405 & 0.464 \\
\hline Dieting & 27 & 36 & 1.667 & 0.262 \\
\hline Jogging & 4 & 5 & 2.750 & 0.029 \\
\hline Less rice consumption & 4 & 5 & 2.000 & 0.033 \\
\hline Doing Yoga & 4 & 5 & 1.500 & 0.044 \\
\hline Intake of less fried foods & 3 & 4 & 2.000 & 0.020 \\
\hline Intake of less sweets & 2 & 3 & 2.000 & 0.022 \\
\hline Doing more work & 2 & 3 & 2.000 & 0.018 \\
\hline $\begin{array}{l}\text { Intake of less non- } \\
\text { vegetarian foods }\end{array}$ & 2 & 3 & 2.000 & 0.017 \\
\hline $\begin{array}{l}\text { Skipping (jumping with } \\
\text { a rope) }\end{array}$ & 2 & 3 & 1.500 & 0.018 \\
\hline Running & 2 & 3 & 1.000 & 0.018 \\
\hline Intake of light food & 2 & 3 & 1.000 & 0.020 \\
\hline Consume only chapati & 1 & 1 & 1.000 & 0.013 \\
\hline Less use of machines & 1 & 1 & 1.000 & 0.013 \\
\hline Visit to gymnasium & 1 & 1 & 3.000 & 0.013 \\
\hline Less cereal intake & 1 & 1 & 2.000 & 0.013 \\
\hline Drinking more water & 1 & 1 & 1.000 & 0.004 \\
\hline Less sugar consumption & 1 & 1 & 3.000 & 0.007 \\
\hline Taking food timely & 1 & 1 & 4.000 & 0.013 \\
\hline Oil massage & 1 & 1 & 2.000 & 0.004 \\
\hline Intake of less red chilly & 1 & 1 & 3.000 & 0.003 \\
\hline No potato consumption & 1 & 1 & 2.000 & 0.009 \\
\hline No sugar consumption & 1 & 1 & 3.000 & 0.004 \\
\hline Lemon water at morning & 1 & 1 & 4.000 & 0.011 \\
\hline Taking honey with water & 1 & 1 & 2.000 & 0.008 \\
\hline Should remain happy always & 1 & 1 & 2.000 & 0.003 \\
\hline Sweeping & 1 & 1 & 1.000 & 0.007 \\
\hline No fried food consumption & 1 & 1 & 1.000 & 0.007 \\
\hline Fasting & 1 & 1 & 2.000 & 0.013 \\
\hline Cooking in soya oil & 1 & 1 & 1.000 & 0.013 \\
\hline Eating besan ka roti & 1 & 1 & 2.000 & 0.007 \\
\hline Dieting & 1 & 1 & 1.000 & 0.013 \\
\hline Total/Average & 161 & 2.147 & & \\
\hline
\end{tabular}

reflects the profound changes in the society and on the behavioural patterns of communities. ${ }^{[1]}$ In developed nations, extraordinary emphasis is placed on thinness, the contrary is the case in developing countries where obesity is culturally accepted and admired. ${ }^{[16]}$ Though the pattern of obesity is still in the early stages in India compared to western countries, it nevertheless needs to be tackled aggressively before it assumes serious epidemic proportions. There is a need to sensitize the public and policy makers about the problem of obesity looking at large in India in future, as prevention is better than cure. While the problem of under-nutrition still exists in many parts of India, the additional burden of obesity due to increasing sedentary lifestyle, junk food habits in some urban and economically sound areas is really alarming. ${ }^{[5]}$ Prevention and control of this serious problem through mass awareness programmes to adopt diversified nutritional food and healthy lifestyle are therefore strongly recommended to contain the epidemic rise of obesity among Indian women.

\section{STRENGTH AND WEAKNESSES OF THE STUDY}

Some strengths as well as limitations of our study deserve attention. Firstly, our study is based in the national capital territory of Delhi which typifies a multicultural and multiethnic population representing India's growing urban scenario. Second, there is dearth of studies in India which examines the awareness of the causes and consequences of excess weight gain and preventive measures among overweight and obese women in India taking a representative data on anthropometric measures at the population level. Our study used actual measured weights and heights without relying on self-reported values of weights and heights, which could otherwise be over or under-estimated. For these reasons, this study is an important contribution to address this existing gap in knowledge in India. Although rigorous methods, for example cross checks and back-checks, were employed to achieve high quality data, some measurement errors cannot be ruled out.

\section{REFERENCES}

1. World Health Organisation (WHO) Global Strategy of Diet, Physical Activity and Health (Obesity and Overweight) London; 2003. Available from: http://www.who.int/hpr/NPH/docs/gs_obesity.pdf] [Last accessed on 2012 Oct 22].

2. Finucane MM, Stevens GA, Cowan MJ, Danaei G, Lin JK, Paciorek CJ, et al. National, regional, and global trends in body-mass index since 1980: Systematic analysis of health examination surveys and epidemiological studies with 960 country-years and 9.1 million participants. Lancet 2011;337:557-67.

3. Popkin BM. The shift in stages of the nutritional transition in the developing world differs from past experiences. Public Health Nutr 2002;5:205-14.

4. IIPS (International Institute for Population Sciences), Macro International National Family Health Survey (NFHS-3), 2005-06, 2007; India, Vol. 1. Mumbai: IIPS; 2007.

5. Garg C, Khan SA, Ansari SH, Garg M. Prevalence of obesity in Indian women. Obes Rev 2010;11:105-8.

6. Misra A, Pandey RM, Devi JR, Sharma R, Vikram NK, Khanna N. High prevalence of diabetes, obesity and dyslipidaemia in urban slum population in northern India. Int J Obes Relat Metab Disord 2001;25:1722-9.

7. Agrawal PK. Dynamics of Obesity among Women in India: A Special Reference to Delhi Unpublished Ph.D. Thesis. International Institute for Population Sciences, Mumbai, India, 2004.

8. International Institute for Population Sciences (IIPS) and ORC Macro. National Family Health Survey (NFHS-2), 1998-99: India. Mumbai: IIPS; 2000.

9. Gopinath N, Chadha SL, Jain P, Shekhawat S, Tandon R. An epidemiological study of obesity in adults in the urban population of Delhi. J Assoc Physicians India 1994;42:212-5.

10. Agrawal P, Mishra V, Agrawal S. Covariates of maternal overweight and obesity and the risk of adverse pregnancy outcomes: Findings from a nationwide cross sectional survey. J Public Health 2012;20:387-97.

11. Altman DG. Missing outcomes in randomized trials: addressing the dilemma. Open Med 2009;3:e51-3.

12. World Health Organization (WHO). Physical status: The use and 
interpretation of anthropometry. Report of a WHO Expert Committee WHO Technical Report Series 854. Geneva: World Health Organization; 1995.

13. Borgatti SP. ANTHROPAC 4.00. Columbia: Analytic Technologies; 1992.

14. Tiwari R, Wagh VV, Babar VY. Obesity: As rural females perceive it. Indian J Med Sci 1998;52:248-52.

15. Kopleman P. Obesity as a medical problem. Nature 2000;. 404(6778):635-43.

16. Ojofeitimi EO, Adeyeye AO, Fadiora AO, Kuteyi AO, Faborode TG, Adegbenro CA, et al. Awareness of obesity and its health hazards among women in university community. Pak J Nutr 2007;6:502-5.
How to cite this article: Agrawal P, Gupta K, Mishra V, Agrawal $S$. Awareness on causes, consequences and preventive measures of obesity among urban married women in India. Int J Med Public Health 2013;3:293-302.

Source of Support: This research received no specific grant from any funding agency in the public, commercial or not-for-profit sectors, Conflict of Interest: The authors declared that they do not have any conflict of interest. 